\title{
The Effect of its Application on Supply Chain Performance Through Green Supply Chain Management in Food and Beverage Industry in Surabaya, Indonesia
}

\author{
Hotlan Siagian $^{1 *}$, Engelbertus William Gomel ${ }^{1}$, and Selvie Josowanto Oei ${ }^{2}$ \\ ${ }^{1}$ Business Management Program, Faculty of Business and Economics, Petra Christian University, \\ Jl. Siwalankerto 121-131, Surabaya 60236, Indonesia \\ ${ }^{2}$ Dayeh University, No.168, University Rd., Dacun, Changhua 51591, Taiwan
}

\begin{abstract}
This study examines the effect of IT application on the supply chain performance through green supply chain management in the Food and Beverage Industry in Surabaya. Data collection is conducted using questionnaires designed with a five-point Likert scale. From 70 questionnaires distributed, 64 were considered valid for further analysis. Data analysis uses the SEM-PLS technique with SmartPLS software version 3.0. This study assesses the extent to which the corporate apply IT and adopt the green supply chain management in improving the supply chain performance. The results of this study indicate that the use of IT applications influences supply chain performance. The IT application affects the green supply chain management. Green supply chain management affects the supply chain management. One of the interesting findings is that the IT application indirectly affects supply chain performance through green supply chain management. The findings of this study provide an insight for the manager on how to improve supply chain management. This research also contributes to the on-going research in the field of supply chain management.
\end{abstract}

Keywords: Efficient supply chain system, Green manufacturing, information technology application

\section{Introduction}

One of the obstacles facing industries in Indonesia today is that they do not have an efficient supply chain system. The result of this inefficient supply chain is high logistics costs. Logistics costs (transportation, warehousing, and inventory) in Indonesia are higher ( $25 \%$ of manufacturing sales) than that of the neighboring countries such as Thailand $(15 \%)$ and Malaysia (13\%). This high cost is primarily associated with the need to bring a high quantity of inventory due to the lack of predictability and unreliability of the logistics chain. Besides, the main problem of the ineffective supply chain system is that many companies use their own/in-house capabilities for their logistics activities. The reason is that the company does not believe in outsourcing services in the field of the supply chain.

\footnotetext{
*Corresponding author: hotlan.siagian@petra.ac.id
} 
In facing the competition, the supply chain needs a fundamental consideration [1]. Every business entity needs to implement suitable logistics activities because logistics activities become an essential element in strengthening competitiveness [2]. Also, every business entity must do innovation because without innovation, there are only setbacks and defeats. The industrial growth in the food and beverage manufacturing in the city of Surabaya is currently significantly increasing. According to the central bureau of statistics (CBS) of East Java (2018), there are 164 large and medium-size companies engaged in the food industry and 7 in the beverage industry in Surabaya. However, the use of information technology in the food and beverage industry is still low, and there are still many business entities engaged in the food and beverage industry that have not cared in environmental sustainability in their business activities

In carrying out supply chain practices in Indonesia, problems of shipping goods between islands in Indonesia emerge when facing a long supply chain, uncertainty in delivery times, and high costs to compensate for at least $70 \%$ of the empty volume on the way home. The impact of these factors will result in high prices of goods and services. Given Indonesia's current supply chain conditions, it indicates that the supply chain sector in Indonesia needs special attention [2]. The supply chain performance denotes the measurement used to assess the achievement of the supply chain network in fulfilling the customer order. The supply chain performance assesses the extent to which the organization fulfills the customer order in terms of the following five indicators: reliability, responsiveness, agility, cost, and asset management efficiency [3].

In dealing with supply chain problems, information technology application denotes a tool in supply chain management that can improve the performance and value of the creation of an organization [4]. The researches show that information technology has revolutionized traditional logistics and supply chains to achieve various benefits such as an improvement in efficiency and responsiveness [5-8]. By utilizing information technology, the flow of goods, services, and information can influence the cost, quality, flexibility, and timeliness of goods delivery, which can benefit the company [9]. This study assesses the IT application as the extent to which the organization has applied the information technology in the following four functions: electronic procurement, electronic data interchange (EDI), enterprise resource planning (ERP), and electronic order fulfillment [10].

Another trending issue in business activities is the threat due to the environmental damage caused by industrial activities. Embedded threats are due to carbon monoxide emissions, discarded packaging materials, toxic materials usage, traffic jams, and other various forms of industrial pollution [11]. Besides, global climate change also has demonstrated the effect of industrial pollution, which could be observed in plain view. Climate change is the most significant environmental challenge facing humanity at this time [12]. The demands of the current global economic environment, the focus of corporate performance has changed from focusing on wealth creation through superior economic performance in asset success, market strength, and obligation, to being focused on environmental performance while achieving high economic performance, in order to achieve a sustainable level of performance [11]. So that environmental factors become one of the world's attention and become a requirement in the industry.

In the face of the challenges of pollution of industrial activities to the environment, green supply chain management emerged as an innovative approach to supply chains that pays attention to environmental sustainability. Green supply chain management aims to eliminate or minimize waste including hazardous chemicals, emissions, energy and solid waste in each supply chain such as product design, procurement, and selection of materials, manufacturing processes, final product delivery and final management activities of products [11]. Designed environmental standards can create innovations that can reduce the total cost of the product or increase its value. The green supply chain management indicates the 
extent to which the organization consider environmental awareness in design and implement the supply chain practices [11]. The green supply chain management is assessed using the following five indicators: green procurement, green manufacturing, green distribution, and green logistics.

Based on the above phenomena, this study examines the effect of IT application on supply chain performance through green supply chain management in the Food and Beverage Industry in Surabaya".

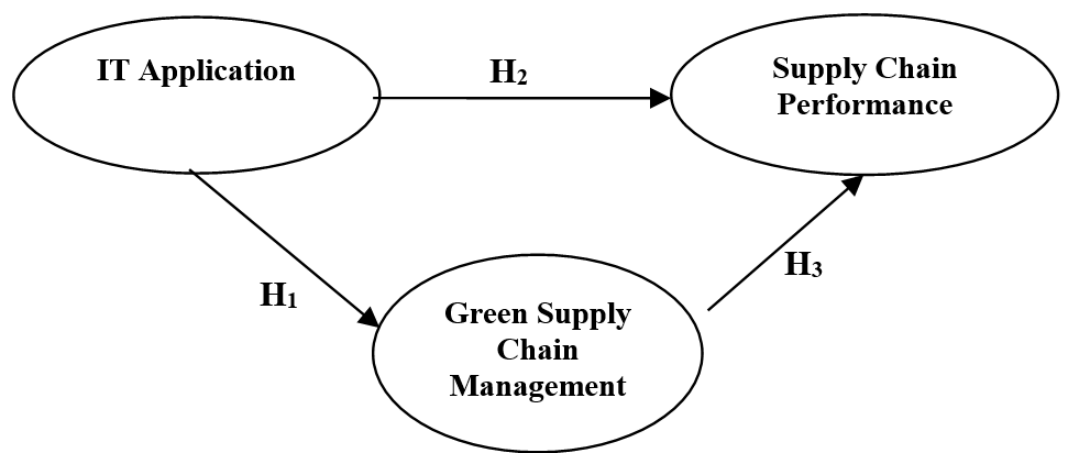

Fig. 1. Research model

Based on the above model, three hypotheses are proposed as follows:

$\mathrm{H}_{1}$ : IT application affects the green supply chain management.

$\mathrm{H}_{2}$ : IT application affects supply chain performance.

$\mathrm{H}_{3}$ : Green supply chain management affects supply chain performance

$\mathrm{H}_{4}$ : IT application has an indirect effect on supply chain performance through the green supply chain management

\section{Research methods}

The type of research used in this study is quantitative research [14]. The quantitative research method is a research method that is based on the philosophy of positivism, used to examine specific populations or samples, sampling techniques, in general, are carried out randomly, data collection uses research instruments, data analysis is quantitative/statistical in order to test hypotheses that it has been fixed.

\subsection{Research population and sample}

The population of this study is 70 manufacturing companies. In the food and beverage industry in Surabaya. Data collection is performed using a questionnaire designed with a five-point Likert scale from 1: strongly disagree up to 5: strongly agree. The questionnaires were distributed to 70 manufacturing companies domiciled in the region of Surabaya, and as many as 64 were correctly filled-in and considered valid for further analysis. The questionnaire consisted of two parts, namely screening questions and the perception of the respondents on IT Application, GSCM, and Supply Chain Performance. Data analysis used the SEM-PLS method. Partial Least Square (PLS) analysis is one of the SEM statistical methods based on variants designed to assess the causal relationship between variables simultaneously. The first analysis is to evaluate the validity of the measurement model in terms of convergent validity, discriminant validity, and reliability of the block indicators of 
each construct. The second step is to examine the hypotheses proposed by looking at the tvalue of each relationship obtained from the bootstrapping process.

\section{Analysis and discussion}

\subsection{Measurement model}

Convergent validity is measured by looking at the outer loading value of each construct indicator. An indicator is said to meet convergent validity if it has a loading factor value> 0.5 . Table 1 shows the value of the factor loading of each indicator item.

Table 1. Convergent Validity of Indicator

\begin{tabular}{lcc}
\hline \multicolumn{1}{c}{ Variable } & & Factor Loading \\
\hline \multirow{4}{*}{ Application } & X01 & 0.889 \\
& X02 & 0.778 \\
& X03 & 0.833 \\
& X04 & 0.854 \\
X05 & 0.844 \\
Green Supply & X06 & 0.847 \\
Chain & Z01 & 0.870 \\
Management & Z02 & 0.753 \\
& Z03 & 0.812 \\
& Z04 & 0.837 \\
& Z05 & 0.782 \\
& Z06 & 0.789 \\
Z07 & 0.783 \\
Supply Chain & Z08 & 0.793 \\
Performance & Y01 & \\
& Y02 & 0.830 \\
& Y03 & 0.730 \\
& Y04 & 0.858 \\
& Y05 & 0.886 \\
& Y01 & 0.830 \\
\hline
\end{tabular}

The factor loading value for each construct is above 0.5 so that it can be declared valid. The Convergent Validity test also looks at the Average Variance Extracted (AVE), which must be above 0.5 .

Table 2. Average Variance Extracted (AVE)

\begin{tabular}{lc}
\hline Variabel & AVE \\
\hline Green Supply Chain & 0.645 \\
Management & 0.708 \\
IT Application & 0.706 \\
Supply Chain Performance & \\
\hline
\end{tabular}

The value of Average Variance Extracted (AVE) in each construct is above 0.5 so that it can be declared passed the convergent validity test. 


\subsection{Reliability test}

A reliability test is used to assess the consistency of a constructing block of indicators. The reliability test can be measured using Composite Reliability $(\mathrm{C} / \mathrm{R})$, which recommended to be higher than 0.7 .

Table 3. Result of Analysis Composite Reliability

\begin{tabular}{lc}
\hline Construct & C/R \\
\hline Green Supply Chain Management & 0.936 \\
IT Application & 0.936 \\
Supply Chain Performance & 0.923 \\
\hline
\end{tabular}

Table 3 demonstrated the value of the composite reliability $(\mathrm{C} / \mathrm{R})$ of each construct. All values have $\mathrm{C} / \mathrm{R}$ higher than 0.7 , which means that all the block indicators of each construct are considered reliable.

\subsection{Discriminant validity}

Discriminant validity constitutes an assessment if the indicator of each construct has loaded with its associated construct higher than that of other constructs. If this is the case, the indicator is considered valid in terms of discriminant validity. Table 4 indicated the result of the assessment, and those indicators are considered valid in terms of discriminant validity.

Table 4. Cross Loading

\begin{tabular}{|l|c|c|c|}
\hline Indicator & GSCM & $\begin{array}{c}\text { IT } \\
\text { Application }\end{array}$ & $\begin{array}{c}\text { Supply Chain } \\
\text { Performance }\end{array}$ \\
\hline X01 & 0.538 & $\mathbf{0 . 8 8 9}$ & 0.587 \\
\hline X02 & 0.489 & $\mathbf{0 . 7 7 8}$ & 0.540 \\
\hline X03 & 0.487 & $\mathbf{0 . 8 3 3}$ & 0.637 \\
\hline X04 & 0.572 & $\mathbf{0 . 8 5 4}$ & 0.584 \\
\hline X05 & 0.497 & $\mathbf{0 . 8 4 4}$ & 0.555 \\
\hline X06 & 0.512 & $\mathbf{0 . 8 4 7}$ & 0.630 \\
\hline Y01 & 0.637 & 0.672 & $\mathbf{0 . 8 3 0}$ \\
\hline Y02 & 0.486 & 0.517 & $\mathbf{0 . 7 3 0}$ \\
\hline Y03 & 0.690 & 0.567 & $\mathbf{0 . 8 5 8}$ \\
\hline Y04 & 0.738 & 0.528 & $\mathbf{0 . 8 8 6}$ \\
\hline Y05 & 0.774 & 0.652 & $\mathbf{0 . 8 8 6}$ \\
\hline Z01 & $\mathbf{0 . 8 7 0}$ & 0.535 & 0.648 \\
\hline Z02 & $\mathbf{0 . 7 5 3}$ & 0.392 & 0.563 \\
\hline Z03 & $\mathbf{0 . 8 1 2}$ & 0.540 & 0.715 \\
\hline Z04 & $\mathbf{0 . 8 3 7}$ & 0.575 & 0.679 \\
\hline Z05 & $\mathbf{0 . 7 8 2}$ & 0.535 & 0.618 \\
\hline Z06 & $\mathbf{0 . 7 8 9}$ & 0.452 & 0.563 \\
\hline Z07 & $\mathbf{0 . 7 8 3}$ & 0.474 & 0.675 \\
\hline Z08 & $\mathbf{0 . 7 9 3}$ & 0.407 & 0.662 \\
\hline
\end{tabular}




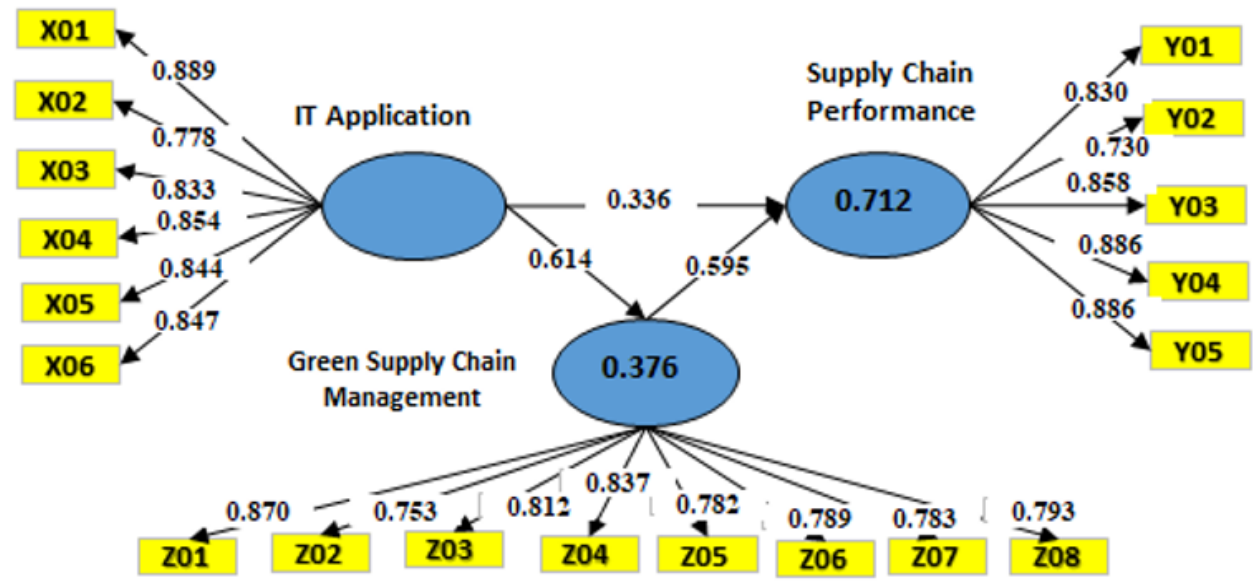

Fig. 2. Analysis results of the model

The results of the analysis of the outer model show that the measurement model of this study is valid, and the next step of analysis is to examine the proposed hypotheses. As described previously, there are three research constructs and three hypotheses. There is one exogenous variable in this study, namely the IT application and one endogenous variable, namely Supply Chain Performance. This study also uses the intervening variable, green supply chain management. Table 5 showed the result of the analysis assessing the R square. The R-square indicated the amount of variance of the endogenous variable that is explained by the exogenous variable. R-square for supply chain performance worth 0.712 , which is considered high. The R-square for the green supply chain management is 0.376 and is considered low.

Table 5. R-Square

\begin{tabular}{lc}
\hline Variable & R Square \\
\hline IT application $(\mathrm{X})$ & - \\
Green supply chain management $(\mathrm{Z})$ & 0.376 \\
Supply chain performance $(\mathrm{Y})$ & 0.712 \\
\hline
\end{tabular}

The results from table 5 show the R-square results, which have a value of 0.376 or 37.6 $\%$. This result shows that the variability of IT application variables affect the green supply chain management by $37.6 \%$, while other variables explained for $62.3 \%$. The R-square IT application results affect supply chain performance has a value of 0.712 or 71.2 green supply chain management influencing supply chain performance by $71.2 \%$, while other variables explained for $71.2 \%$.

\subsection{Hypothesis testing}

Hypothesis testing aims to determine the correlation or relationship between each variable studied. Testing the hypothesis in this study uses a significance value of $5 \%$ with a statistical t-value of 1.965 . Then the hypothesis acceptance criteria are when t-statistics> 1.965 .

Table 6 demonstrated the result of the analysis. All the t-values are higher than 1.96. Hence, all the hypotheses are supported. The first hypotheses, IT application affects the green supply chain management, is supported. The IT applications will influence the green supply chain management achievement [15]. IT applications in their business activities will 
help companies obtain various forms of information that can improve the green supply chain activities.

Table 6. Hypothesis Test Results (T-Statistics)

\begin{tabular}{lcc}
\hline \multicolumn{1}{c}{ Influence } & T-statistic & Path Coefficient \\
\hline IT application $\rightarrow$ gGreen Supply Chain Management (H1) & 7.822 & 0.614 \\
IT Application $\rightarrow$ Supply Chain Performance (H2) & 3.286 & 0.336 \\
Green Supply Chain Management $\rightarrow$ Supply Chain & 5.498 & 0.595 \\
$\begin{array}{l}\text { Performance (H3) } \\
\text { IT Application } \rightarrow \text { Green Supply Chain Management } \rightarrow\end{array}$ & 4.332 & 0.365 \\
Supply Chain Performance (H4) & & \\
\hline
\end{tabular}

The IT applications cover the application of electronic procurement activities to support the procurement of raw materials, production equipment, and company needs. Besides, IT applications help minimize transportation activities that cause environmental damage, thereby reducing air pollution. Through the implementation of e-procurement, the company will save time and transportation costs of raw materials or equipment. Besides, eprocurement practices will be more environmentally friendly since there is no need for a paper to make a purchase order to buy goods. The company does not need to issue a letter of purchase or receive a purchase receipt physically so that the level of pollution due to waste paper can be eliminated.

The second hypothesis, IT application, affects the supply chain performance, which is supported by the t-value of 3.286. IT application affects supply chain performance. The more integrated the IT application, the more significantly enhances the supply chain performance. This finding means that appropriate IT applications produce excellent supply chain performance. To deal with the continually changing business environment, companies need tools to help them cope with business changes. IT application is one of the tools to help companies face business challenges that are continually changing at any time. By using IT, companies can create various strategies that can help them in creating better products that have more competitive prices. With IT applications, the company will also enhance its competitiveness as they are always up to date with the current market needs. In the use of IT applications, food and beverage companies in Surabaya intensely conduct eprocurement activities to support the procurement of raw materials, production equipment, and company needs. Using electronic procurement will make the company's activities more efficient because the procurement activities of the company's needs are faster and save costs.

The third hypothesis, green supply chain management, influence the supply chain performance, is also empirically supported with the t-value of 5.498. The adoption of the green supply chain management help provides a new value for consumers and markets in term of environ. Green supply chain management creates environmental friendly activities and benefits cost-efficiency simultaneously. The reason is that they use environmentally friendly raw materials, recyclable packaging materials. Besides, green supply chain management conducted environmental friendly systems through maximizing logistics capacity, and use the fastest and most efficient route, so that in addition to reducing transportation costs. Food and beverage companies in Surabaya are conducting green logistics activities to support the company's transportation activities even though in different levels of implementation. Implementing the green logistics activities benefit the company from lower costs, saving time, maximizing transportation capital capacity and in the end, improve supply chain performance [16].

One of the interesting findings from this study is the presence of the mediating role of the green supply chain performance. The IT application affects the green supply chain management and supply chain performance. Also, IT application affects the supply chain 
performance indirectly through the green supply chain performance. Hence, the IT application provides a double impact on supply chain performance. Based on the result, the model of this study is considered useful in providing insight for the supply chain manager that the IT application and the adoption of green supply chain management could improve the supply chain performance.

\section{Conclusion}

The present study was designed to examine the effect of IT application on supply chain performance through green supply chain management in the food and beverage industry in Surabaya. The following conclusion has been withdrawn. First, IT application has a positive effect on green supply chain management. The more intense the use of IT applications, the higher its impact on implementing green supply chain management. Second, IT application has a positive effect on supply chain performance. The application of IT in integrating the business process enhances supply chain performance. Third, the adoption of green supply chain management has a positive effect on supply chain performance. One of the interesting findings is that IT application has an indirect effect on supply chain performance through the adoption of green supply chain management.

In summary, the IT application affects the supply chain performance either directly or indirectly. This result provides an insight for the manager on how to enhance the supply chain performance through the application of IT and the adoption of green supply management practices. This study also contributes to the current research in the field of supply chain management.

\section{References}

1. M. Casson, Journal of Supply Chain Management, 49,2:8-13(2013). https://onlinelibrary.wiley.com/doi/abs/10.1111/jscm.12009

2. T.M. Simatupang, Transportation Research Part E: Logistics Transportation Review, 99,14-33(2013).

https://www.academia.edu/3767860/Logistics_and_Supply_Chain_in_Indonesia_Eme rging_Practices

3. I. Koçoğlu, S.Z. Imamoğlu, H. Ince, H. Keskin, Social and Behavioral Sciences, 24:1630-1649(2011).

https://www.sciencedirect.com/science/article/pii/S1877042811015448

4. A.P.D. Barros, C.S. Ishikiriyama, R.C. Peres, F.S. Gomes, Procedia Computer Science, 55:698-705(2015).

https://www.sciencedirect.com/science/article/pii/S1877050915015525

5. A. Gunasekaran, Z. Irani, K.-L. Choy, L. Filippi, T. Papadopoulos, International Journal of Production Economics. 161:153-166(2015a).

https://www.sciencedirect.com/science/article/pii/S0925527314004150

6. A. Gunasekaran, E.W.T. Ngai, European Journal of Operational Research. 159(2):269-295(2004). https://www.sciencedirect.com/science/article/pii/S0377221703005186

7. A. Gunasekaran, N. Subramanian, S. Rahman, Transportation Research Part E: Logistics Transportation Review. 74:1-10(2015b). https://www.sciencedirect.com/science/article/pii/S1366554515000034

8. D. Prajogo, J. Olhager, International Journal of Production Economics. 135:514522(2012. https://www.sciencedirect.com/science/article/pbkii/S0925527311003872

9. F. Ye, Z. Wang, Computers \& Industrial Engineering, 65,3:370-377(2013). https://www.sciencedirect.com/science/article/pii/S0360835213001137 
10. H. Zhou, W.C. Benton, Journal of Operations Management, 25,6:1348-1365(2007). https://www.sciencedirect.com/science/article/pii/S0272696307000113

11. T.A. Chin, H.H. Tat, Z. Sulaiman, 12th Global Conference On Sustainable Manufacturing, 26:695-699(2015). https://www.sciencedirect.com/science/article/pii/S2212827114008488

12. Y. Dou, Q. Zhu, J. Sarkis, European Journal Of Operational Research. 233,2:420 431(2013). https://www.sciencedirect.com/science/article/pii/S0377221713002129

13. M. Porter, C. van der Linde, Green and competitive - ending the stalemate. In: Business and the Environment. R. Welford, R. Starkey (Eds.), London: Earthscan (1996), 61-77. https://www.hbs.edu/faculty/Pages/item.aspx?num=5522

14. Sugiyono. Metode Penelitian Bisnis: Pendekatan Kuantitatif, Kualitatif, dan R\&D [Business Research Methods (Quantitative, Qualitative, and R\&D Approaches]. Bandung: Alfabeta (2009). [in Bahasa Indonesia]. https://scholar.google.com/scholar?cluster $=10328650190657588078 \&$ hl=en\&oi=scho $\underline{\text { larr }}$

15. M. Subramani, MIS Quarterly. 28,1:45-73(2004). https://www.jstor.org/stable/25148624

16. N. Subramanian, M.D. Abdulrahman, X. Zhou, Transportation Research Part E: Logistics Transportation Review. 74:86-98(2014). https://www.sciencedirect.com/science/article/pii/S1366554514001100 